\title{
LEGAL AND ECONOMIC IMPLICATIONS OF THE EMERGENCE OF QUASI-PUBLIC WEALTH
}

\author{
ROBERT J, LYNNं
}

\begin{abstract}
"The nineteenth century was characterized by the expansion of freedom; the twentieth is characterized by the search for security."1
\end{abstract}

It is a commonplace that the face of America is changing. Less familiar is the fact that the surface changes which are so readily discerned reflect fundamental shifts in the underlying political, social and economic structure of the nation. More particularly, there is no general awareness that property-the bulwark of the legal order-is changing its form and function in American society.

Legal rules tend to change slowly, and property doctrines change very slowly indeed. Just as doctrine affects property form, so too form affects property doctrine. But change in form may outstrip the evolution of doctrine; and if such a difference in rate of change remains unnoticed for a substantial period of time, form suffers, and society with it. Therefore prompt recognition of significant shifts in form, and careful adjustment of doctrine to changing form, assume at times a critical importance. Now is such a time.

The identification of form, quickened public interest in an emerging form of quasi-public wealth, some questions posed in adjusting traditional doctrine to an emerging form, and the impact of shifting property forms on the devolution of wealth make up the subject matter of this paper.

\section{Forms of Property-Old and New}

In a democratic society where the individual is the focus of attention, it is only natural that among the various methods of devolution of wealth receiving general approval, ${ }^{2}$ the transmission of property from the individual donor to his natural dependents and successors ${ }^{3}$ enjoys the greatest measure of public

$\dagger$ Associate Professor of Law, Ohio State University College of Law.

1. Kerr, Social and Economic Consequences of the Pension Drive, in Natronal Irdustrial Conference Board, Handbook on Penstons 83 (1950).

2. In general, the aggregate of claims to wealth devolves from generation to generation through (1) private arrangements or their equivalents, e.g., inter vivos gift (in trust or not), testamentary gift (in trust or not), intestate succession, close corporations; (2) quasi-public institutions, e.g., great commercial corporations, insurance companies, trust companies, charitable trusts, philanthropic foundations, nonprofit corporations; (3) governments or their equivalents, e.g., federal, state and local governments holding lands, installations, monuments or funds, either directly or indirectly (through government-sponsored corporations).

3. For a description of this particular aspect of the general process, as developed by Professor Myres S. MicDougal, see Lynn, The Rule Agarnst Perpetuirres as AN IN- 
solicitude. Elaborate machinery is available for effectuating the transfer smooth$1 y$, with the least diminution of the wealth base and minimum inconvenience to the beneficiaries. Indeed, the creation, growth and conservation of private fortune, and its ultimate disposition among claimants-particularly dependents of the donor-are commonly deemed indispensable elements of dynamic capitalism $;^{4}$ and diverse components of society give much attention to increasing the area of freedom within which the phenomenon flourishes-all this despite the admonition reverberating down through the centuries that man should not lay up for himself treasures on earth.

The transfer of property from the individual donor to his successors may be effected in a variety of ways, ${ }^{5}$ and the techniques of disposition finally employed are often the result of a careful weighing of time, place and circumstance by the donor and those specialists who engage in the artful task of maximizing the realization of today's expectations despite the inexorability of tomorrow's change. The dispositive devices open to the man of means seem limitless, but limits there are $;^{6}$ and it is the draftsman's task to temper the bent of the donor's

strument of Conmuntex Policy c. 1 (unpublished thesis in Yale Law School Library 1952).

4. "The ability to make testamentary bequests, . . is indispensable to the advancement of society in wealth and civilization... Without this power a man is not the master of his own fortune ...." McCulloch, Succession to Property 10 (1848). "It is probable that the incentive to work and to save would be very seriously impaired if family inheritance were not allowable. ..." Stamp, Inheritance: Economic Aspects, in 12 EncyccoPEDLA BRTTANNICA 356 (1936). But there is dissent. "The first observation to make is that this argument considers only those who make a fortune and not those who inherit it. It is also well to note... that mere productivity is not necessarily conducive to social welfare.... The argument that men would not work efficiently . . . ignores the vast rôle that non-pecuniary incentives play in men's working lives. . . [and] gives to the anticipation of death a greater rôle than it plays in the daily conduct of most men." CoHEN, The Birthright of Esau, in LAw AND ThE Social. ORder 27, 30 (1933). And Stamp himself writes: "It may be said ... that the advantages of a system of inheritance from the point of view of national production rest almost entirely in its psychological influence upon saving. ..." Stamp, supra at 357.

5. See Scott, Control of Property by the Dead, 65 U. PA. L. Rev. 527, 632 (1917).

6. See Scott, supra note 5. The notion that some restraints on freedom of disposition are justifiable has met with resistance from time to time:

"But though it must be owned that this is a question of much difficulty [a forced share to the children of the donor], ... it would seem that the reasoning of those who argue in favour of the unrestrained power of devising by will is the most satisfactory. It might, perhaps, be expedient (though we do not lay much stress on the suggestion) to encroach so far on this principle as to make the fortunes of people possessed of property, in the event of their dying while their children are in a state of pupilage, responsible for their maintenance and education till they come to maturity, or are in a condition to support themselves. . . But it would be inexpedient to go farther than this."

McCulLocH, op. cit. supra note 4, at 13.

"In modern industrialized societies, where the conception of property has become highly individual ... the tendency has been to leave inheritance as free as possible from regulation by the state and therefore to extend continuously the right of an unfettered bequest." Cole, 
desires and create a plan of disposition that carries out to the highest degrec his articulated wishes, yet is sturdy enough to withstand the erosion of a changing world.

Traditionally, the properties of the donor that have received the most deroted attention from both his successors in interest and society in general have consisted of more or less readily identifiable wealth and claims to wealth, tangiblc and intangible-land, personalty, monies, securities. The acquisition, retention and ultimate disposition of material goods is a process of everlasting fascination. and in the foreseeable future that process will continue to absorb the interest and energies of innumerable individuals seeking to secure the greatest possible share in the stake available for distribution. Such individuals will be attender by a much smaller group-lawyers, accountants, insurers, bankers, economists -specializing in effecting the distribution in an orderly fashion, minimizing friction between competitors for goods, and satisfying the demand for certainty, ritual and recording which commonly accompanies transfers of wealth.

Recognizing the persistence of the traditional is not, however, enough for a thoroughgoing appraisal of the devolution of wealth as it exists and will probably develop in the United States. Any realistic survey of the present property scene must reveal that as the original acquisition of massive material wealth becomes more difficult, other forms of "property"- - often more elusive, more subtle-become a larger part of the donor's bounty. ${ }^{7}$ Claims to social security benefits, participating shares in pension or profit-sharing plans, certificates of membership in group life insurance schemes-these have already been accorded a place in any complete appraisal of the modern estate. ${ }^{8}$ Not so easily fitted into the traditional categories of wealth are the good family name left

Inheritance, 8 ENcyc. Soc. Scr. 35, 37 (1932). And imposing restraints is a problem of no little difficulty:

"If unlimited freedom of inheritance and of bequest are not natural rights, it at once becomes an important question how they may be limited, and in general the test applied is that of 'social desirability.' But the definition of what is socially desirable has proceeded in the past too much upon distinctions as to abstract justice or fairness, and very little examination has been made, or estimate attempted, of the effects upon production of different practices. Although diffusion of wealth and 'better' distribution of wealth have been used as reasons for limitation and legal direction, the economic consequences are not clearly known or distinguished."

Stamp, supra note 4 , at 357.

7. "There is one more factor of the greatest moment: the psychological attitude of a people determines, to a far greater degree than is generally supposed, which goods shall be brought within the bounds of the price system. In this respect modern capitalism is much more sensitive and far reaching than, for example, the mediaeval handicraft system. It might even be said that the commercial-capitalist outlook creates values out of dust. . . . [T] here is a tendency in the general course of economic development for new objects continually to be drawn into the sphere of market transactions and price valuation and consequently for the bases of calculable wealth to shift and change." Weyermann, National Wealth, 11 Encyc. Soc. Scr. 227, 230 (1933).

8. Woraiser, Personal Estate Planning in a Chanjging World 97-122, 165-71 (6th ed. 1952). 
hy a deceased; political, fraternal, professional or union ties that he originated, strengthened or developed; provision made by him with the family firm for the apprenticeship of his successor in interest; placement of a favored dependent with a commercial, financial or charitable institution ${ }^{9}$ in which the deceased had influence. ${ }^{10}$ Some of these phenomena, products of power, are undoubtedly older than their more recognizable counterparts. But such phenomena do not lend themselves readily to count or measure. Not all can be stored, safeguarded, divided and transmitted. Consequently, they are easily and frequently overlooked. Though the power position of the donor has important implications for his successors in interest, difficulties of valuation may prevent its inclusion in the itemizing of an estate. ${ }^{11}$ Even so, legacies of this impalpable sort have a place in any accurate survey of the devolution of wealth; and subtleties of distinction and difficulties of assessment do not justify failure to take full account of the manifold forms that the valuable takes in a complex capitalistic society.

However, one need not range far beyond the traditional to detect shifts and trends in property forms, doctrines and practices. Within the usual categories of wealth, change has of course been the rule rather than the exception. It is common knowledge, for example, that as mercantilism displaced feudalism, the overriding importance of land as a wealth base diminished. Over the centuries, too, particular property doctrines have emerged, flourished and died-or nearly so. ${ }^{12}$ Dispositive devices were invented, utilized and ultimately discarded. ${ }^{13}$ Property management shifted, bit by bit, from the private individual to the impersonal corporation. ${ }^{\mathbf{1 4}}$ So it has been, and so it is likely to continue.

9. "The foundation is a mechanism which has been frequently used to preserve family control of a family business. . ." CASEy, LASSER \& LoRD, TAX PLANning For FoundaTTONS AND Charitable Grving, Introduction (1953). "Since the grantor will probably be in control of the charity through control over the directors or trustees, the inability to give a direction to accumulate is not ordinarily very important." Id. at 41.

10. Cf. Weyermann, supra note 7, at 228:

"Objects included under national wealth may be either material or immaterial, as, for instance, advantages of position, of productive efficiency or of monopolistic control. The decisive feature is that they can command a price in the market and be converted into money terms."

11. Unless, of course, a continuing business interest constitutes part of the estate, and even then valuation problems do not necessarily disappear: "[Accounting] authorities generally disapprove both setting up of goodwill on the basis of history or prospects of high earnings and the similar writing up of the value of intangibles which had been purchased. There has been disagreement, however, as to intangible values developed through research. ... The 'cost' principle would not forbid capitalizing such expenditures, but the difficulty is in identifying the expenditures which justify . . capitalization. . ." KATz, Accounring 197 (1954). Appraising the assets of a going concern involves consideration of the power position of the owner whether characterized as "goodwill" or not.

12. An example is the destructibility rule. See Simes, Future Interests 48 (1951).

13. An example is the ancient use. See Martland, EQuity 23-42 (2d ed. 1936).

14. "The translation of perhaps two-thirds of the industrial wealth of the country from 
The continuity and inevitability of change make the task of the property lawyer a difficult one. The draftsman intent on accurate description, prescription and prediction with regard to that "euphonious collocation of letters which serves as a general term for the miscellany of equities that persons hold in the commonwealth" ${ }^{15}$ must try to identify as precisely as possible the emerging forms of wealth; the relative position and importance of varying forms; the probable direction of the changes in form; the rate of change applicable to the diverse forms; and the political, social and economic forces that affect all these. He must master the intricate doctrines applied by lawyers and judges in manipulating the forms. He must be aware of the multiple functions of doctrine and of the constant confusion of function. And of course he must anticipate trends, twists and erosions of doctrine.

\section{The Entergence of Institutional Wealth}

Popularly, claims to wealth are classed as either "public" or "private," and for some purposes such a rough breakdown of interests is probably adequate; for even if interest in refinement of property notions exists, it is not always feasible or advisable to attempt more accurate description. But for an effective understanding of the property arrangements of the modern community, the dichotomy is too rigid. That it endures testifies to a deep-seated aversion to the refinement of property classifications. That many a charitable institution exists only at the sufferance of society ${ }^{10}$ is ignored. That corporate holdings have a public nature is a notion of only comparatively recent origin. ${ }^{17}$ Allusions to institutional claims to resources often assume their "private" character even though institutional claims have grown enormously.

But there are indications that the customary antipathy to clarification of fact is breaking down. There is to some degree an increasing willingness to examine familiar institutions and practices in order to determine whether or not

individual ownership to ownership by the large, publicly financed corporations vitally change's the lives of property owners. ..." Berle \& MeANs, The Modern Corporation and Private Property vii (1932).

15. Hamilton \& Till, Property, 12 ENcrc. Soc. Sci. 528 (1934).

16. "Although organized charity for centuries has been relatively free from surveillance and regulation by government, nevertheless, the permission to operate is a grant given by state governments or occasionally by Congress." NEw YORK LEGrsLATIve DocuMENT No. 26, at 15 (1954). "It is frequently implied . . that private benefactions would cease if it were not for tax exemptions of contributions to and of property of these private [charitable] organizations. Tax exemption is cited as a necessary incentive to private giving. ..." Krlocgh, Exemptions to Edncational, Philanthropic and Religious Organiza. tions, in TAX ExeMrtions 23, 30 (1939).

17. "Corporations where this separation [of ownership and control] has become an important factor may be classed as quasi-public in character in contradistinction to the private, or closely held corporation. . ." BerLe \& MeANs, op. cit. supra note 14, at 5. "It is ... misleading to present the vast operations of corporate concentrates as 'private'except in the sense that they are not statist. . . " Berde, THe 20TH Century Capitalist Revolution 1.1-12 (1954). 
results attained through them square with objectives sought. That willingness is evidenced by comment, ${ }^{18}$ discussion and inquiry, both public ${ }^{19}$ and private, ${ }^{20}$ into the ramifications of conventional property devices in the light of modern requirements. There is, most notably, a sudden upsurge of public interest in institutional claims to wealth.

The tremendous growth of institutional holdings is a relatively recent phenomenon $;^{21}$ the challenge to traditional property notions is relatively new. In a day when land was the chief form of wealth, and right and duty lay between man and man or man and God, there was perhaps little need for great refinement of property ideas. Inasmuch as all land was held ultimately of the king, the public nature of property interests was in feudal days self-evident. And even as individualism asserted itself, simplicity of classification remained, for no labyrinth of institutional arrangements had as yet developed to plague the mind. Acquisition of properties by religious and charitable organizations was regulated to some degree, ${ }^{22}$ and in any event public supervision of such holdings was virtually assured as a consequence of the religious upheaval worked by Henry VIII. ${ }^{23}$ Use of the private express trust as a wealth devolution device was confined pretty much to a comparatively small number of landed English families.24 Even when the private corporation eventually emerged to flourish as the instrument of mercantilism, its evolution was comparatively slow; and for good or ill, the legal profession assured its predominantly "private" character

18. E.g., Andrews, This Business of Giving, The Atlantic, Feb. 1953, p. 63 ; Drucker, The New Tycoons, Harper's Magazine, May 1955, p. 39; Whyte, What Are the Foundations Up To? Fortune, Oct. 1955, p. 110; Wilson, Pension and Profit Sharing Plans-A Field for New Trust Business, Trust BunL., Nov. 1953, p. 20; Wynn, Charitable Organiaations, 92 Trusts \& Estares 762 (1953).

19. E.g., Committee on the Law and Practice Relating to Charitable Trusts, Report, CMD. No. 8710 (1952) ; Hearings Before the Select Committee to Investigate Tax-Exempt Fonndations and Comparable Organizations, 82d Cong., 2d Sess. (1953) ; H.R. REP. No. 2514, $82 \mathrm{~d}$ Cong., 2d Sess. (1953) ; Hearings Before the Special House Committee to Inzestigate Tax-Exempt Foundations and Comparable Organizations, 83d Cong., 2d Sess. (1954) ; H.R. Rep. No. 2681, 83d Cong., 2d Sess. (1954) ; Straub, Whose Welfare? A Report on Union and Exrployer Welfare Plans in New York (1954).

20. E.g., Andrews, Attitudes Toward Giving (1953); Andrews, Corporation Giving (1952) ; Andrews, Philanthropic Giving (1950); Deartng, Industrial Pensrons (1954); Fisch, The Cy Pres Doctrine in the United States (1950) ; Flexner, Funds and Foundattons (1952); Krger, Operating Princtples of the Larger Foundations (1954); Taylor, Public Accountability of Foundations and Chardtable Trusts (1953); The Manual of Corporate Grving (Ruml ed. 1952).

21. Andrews, Philanthropic Giving 90 (1950); Berle \& Means, op. cit. supra note 14, at 10-17; DeARing, op. cit. supra note 20, at 30-65.

22. Highmore, History of Mortarain 12-23 (2d ed. 1809) ; Holdsworth, Historical INTRODUCTION TO THE LAND LAW 109 (1927).

23. KIGER, ap. cit. supra note 20 , at 19.

24. Common sense would so suggest, and authorities indirectly substantiate the notion. 4 Holosworth, History of English Law 475 (1924); Radcliffe, Real Property Law 101-14 (2d ed. 1938). 
until nearly the end of the nineteeth century ${ }^{25}$ without undue strain on traditional property doctrines.

As the pace of the Industrial Revolution quickened in the United States, the nature of the corporation changed. The flourishing family firm, with stock closely held, was swallowed up in the great corporation, with ownership divorced from effective control. ${ }^{26}$ Former owners of small businesses became salaried employees within industrial empires, and millions of workers-inmigrants disgorged at eastern ports and farm laborers attracted by high wages -flocked to factories in urban areas. ${ }^{27}$ The social consequences of this revolutionary economic change are still with us. One of them, the sense of insecurity engendered in the individual by his integration into an unthinking, impersonal production machine, found expression not only in the movement to organize labor, but also in the effort to enlarge the function of the benevolent societies that flourished toward the turn of the century. ${ }^{28}$ When the attempts of government and traditional charity to relieve the plight of the unemployed. the infirm, the widow and the orphan proved inadequate, unions and fraternal organizations tried to stem the tide of human misery not only by pressing for effective legislation, ${ }^{29}$ but by making various welfare arrangements of their own. ${ }^{30}$

There was no leisurely development of the numerous plans for achieving the Elysian state of security. On the contrary, the movement was characterized by high, impatient hopes, over-ambitious undertakings, and consequent frustrated expectations. The waste begotten by poor planning and inept management of the various vehicles of progress has never been calculated; but it is a fact that the early attempts of quasi-public associations to meet the demand for certainty in the ordering of human affairs met with disappointment. ${ }^{31}$

The period following the first World War was one of retreat for labor forces, ${ }^{32}$ and the quest for security on a mass scale had to await the resurgence of the union movement toward the close of the second administration of Franklin D. Roosevelt. Despite occasional set-backs, the power of the unions was assured at the outbreak of World War II, and a chance combination of factors reinforced their wartime demands for a share in corporate profits beyond the mere increase of wages. ${ }^{33}$ As a result of union pressure, corporation after corporation

25. Berle \& MEANS, op. cit. supra note 14 , at 13.

26. Id. at 2 .

27. Dulles, Labor in America 96-99 (1949).

28. 1 Bacon, Benefit Societies and Life Insurance $\$$ 1a-4 (3d ed. 1904); O'DonNell, History of Life Insurance in the Forkiative Years 624-32 (1936).

29. Person, Industrial Welfare Work, 15 Encrc. Soc. Scr. 395, 398 (1935).

30. Peterson, American Labor Unions 179 (2d ed. 1945).

31. Huebner, Life Insurance 379 (4th ed. 1950); O'Donnell, op. cit. supra note 28, at 628; Buckmaster, Union Philosophy on Pensions, in National Industrial Conference Board, Handeook on Penstons 75 (1950).

32. DuLles, op. cit. supra note 27 , at $242-63$.

33. "The great spawning of plans first came in the fall of 1942 . The urgent wartime pressure to expand production led to a wild hunt for manpower, but the raising of wages, 
during and after the war made welfare concessions undreamed of in an earlier day. Unemployment compensation benefits secured in the mid-thirties were complemented by health, profit-sharing and retirement benefits broad in scope and generous in amount. The sense of security hitherto available only to the man of means came within the grasp of the most powerful segment of the employee class-the organized. A product and a gauge of the success of the long struggle for security is the spectacular increase in welfare funds over the past ten years. ${ }^{34}$ A new institution, with massive claims upon the resources of the community, has emerged to join the great corporation as a phenomenon of the twentieth century.

Although the social effects of mass consumption of security are yet unknown, it is clear that the ferment of the past few decades has major implications for the law and the lawyer. For the new claims to wealth do not fit comfortably into the traditional patterns. They are neither public nor private, but quasi-public : quasipublic because whatever the device enveloping the claim, whatever the doctrine applied to the device, whatever the institution and the practice through which device and doctrine achieve meaning, the theme of public interest runs through them all. As a group, quasi-public institutional claims have received little attention from the lawyers: despite the flood of comment on the activities of great commercial corporations, charitable trusts and nonprofit corporations have existed for years in relative obscurity. Now such comparatively old property devices are being increasingly used, and used in new and unfamiliar ways. There is, for instance, an increased utilization of the trust by groups who cannot be identified with the beneficiaries of the traditional charitable trust, and who are equally alien to the old family settlement. If these new developments have not been systematically dealt with by the legal profession, they have at least caused considerable unease in the public at large. The reasons for this unease will bear examination.

the customary lure extended to attract additional employees or retain those currently on hand, while not prohibited, was inhibited. Many companies, with profits to spare, established pension plans-the current cost in the face of excess-profit taxes was nominal. . . .

"What was at first voluntary, if induced, later became coerced. . . When the Federal Government . . . completed the Krug-Lewis agreement in May, 1946, pension and welfare plans became a bargaining issue par excellence. ...

"Then in April, 1948, ... the [National Labor Relations] Board ruled . . . that 'wages and other conditions of employment' included pensions; and henceforth employers must bargain about them. Finally in September, 1949, the steel fact-finding board . . submitted its recommendations that the basic steel companies and the United Steelworkers of America bargain on pensions. ..." Kerr, supra note 1, at 83-84.

34. "[B]anks in this state [New York] at the end of September, 1955 , held $\$ 7.5$ billion of these funds. This constituted almost 60 per cent of all such trusteed funds in the United States." Mooney, Pension and Other Earployee Welfare Plans-A Survey of Funds Helu by Stute anu Natronal Banks in New York State i (1955). "The pension funds of U.S. corporations at the end of 1954 are estimated to hold $\$ 11.2$ billion of assets according to a survey undertaken recently by the Securities and Exchange Commission." Corporate Pension Funds, 1954, SEC Statistical Series Release No. 1335, Oct. 12, 1955. 


\section{Quickened Public Interest in Quasi-Public Wealth}

In 1935 Congress passed the Social Security Act. Some twenty years later important segments of Big Industry, under bludgeoning by Big Labor, capitulated to the Guaranteed Annual Wage. ${ }^{35}$ Both the adoption of social security legislation by government and the acceptance of wage responsiblity by industry have been hailed as landmarks of progress in this country, ${ }^{36}$ but without detracting in the least from the very considerable importance of these phenomena, one can view them as something less than monumental and as something more than isolated. The deferment of claims to current consumption in exchange for a "right" to future consumption is not new. The entry of government intu schemes for the care of the old and the dependent was both preceded and accompanied by welfare legislation of a less comprehensive kind. The push by the labor unions for a guaranteed wage followed a fifteen-year battle for acceptance of insurance, health, pension and welfare plans. It was not, then, the novelty of social security or the guaranteed wage that won them unique recognition; rather, it was the aura of drama surrounding their emergence. Did the opinion of Lord Nottingham in The Duke of Norfolk's Case ${ }^{37}$ kick up a comparable storm? Probably not. Yet in the field of property law that case is regarded-and properly so-as a landmark.

If it is true that deferment of current consumption in exchange for a claim to future goods is not a new phenomenon, then what accounts for the furor aroused by the extension of social security benefits to new categories of claimants, ${ }^{38}$ or adoption, in principle at least, of the guaranteed wage? Some readily verifiable causes for apprehension can be identified. But to a large extent the factors influencing opinion can only be hypothesized, for they lie embedded in legal, economic and social attitudes not yet subjected to extensive study.

For example, it is undoubtedly true that the number of persons initially affected by the enactment of social security legislation was in itself enough to warrant widespread discussion of the program adopted by Congress. Salaries and wages of millions of persons were subject to deductions. Contributions were exacted from employers. The cost of administering the plan ultimately fell on the general public. Naturally, heated discussion of the merits and deficiencies of the measure were commonplace.

By way of contrast, how many persons were immediately affected by the opinion issued by the Supreme Court of the United States in Nichols v. Eaton ${ }^{3 a}$

35. It is sometimes said that what labor garnered in the bargaining of 1955 was not guaranteed, was not annual, and was not a wage. For the purposes of this papor, the controversy over word-choice may be ignored.

36. But not universally so. For a succinct statement of the usual arguments advanced against acceptance of the guaranteed wage principle, see Slichter, Labor's New Victorl, The Atlantic, Sept. 1955, p. 63.

37. 3 Ch. Cas. 1, 22 Eng. Rep. 931 (1682).

38. Cf. Bigger Benefits for 75 Million People, U.S. News \& World Report, Sept. 3. 1954 , p. 44.

39. 91 U.S. $716(1875)$. 
-the case that gave impetus to the spendthrift trust in this country, ${ }^{40}$ and that set John Chipman Gray to writing his celebrated book Restraints on Alienation ?41 Despite Gray's forebodings of dire results to follow, acceptance of the spendthrift trust apparently aroused no particular apprehension outside the legal profession; and such trusts are now valid in nearly all the states. ${ }^{42}$

Whatever are the reasons that prompted judicial recognition of disabling restraints on equitable life interests, it is self-evident that when the characteristics of a device hit upon to care for dependents and successors are shaped in comparative obscurity, when its acceptance of rejection is determined by an isolated professional group, when its utilization is confined to a relatively small proportion of the population, it is not at all remarkable that no stirring controversy surrounds its emergence. But when the devices embodying claims to future goods are hammered out by legislatures or by union-management teams working in the glare of modern communications systems, public interest must inevitably be caught up in the solutions arrived at.

General interest in quasi-public wealth has then been awakened by the dramatic emergence of new claims to the resources of the community. Furthermore, outright uneasiness has been provoked in some quarters by the very size of the "funds" accumulating under the innumerable retirement, pension, profit-sharing and health and welfare plans. Many call for a deduction from current salaries or wages, to be matched in many instances by the employer. This deducting and matching process has produced an aggregate of funds mounting into billions of dollars $;^{43}$ and it has given rise to a plethora of political, legal, economic and social questions-questions that might have remained unasked were the public interest less apparent. These are, moreover, questions that bench and bar must be prepared to help answer-perhaps have already been called upon to answer.

Representative but by no means exhaustive of the problems raised by the new quasi-public institutional claims are the following. Precisely what place should be accorded the aggregate of claims in the channeling of capital investment? Traditionally, we have tended to insist that the private insurer and the fiduciary invest somewhat conservatively. Is it wise to require that the managers of the newer forms of quasi-public wealth shy away from the "speculative," even though choice among traditional investment outlets is in fact restricted, and even though inflation proves, in the long run, to be "normal"? Whatever the legal rule, should it be permissible by appropriate language in the "indenture," "contract," "articles" or "policy" to free the managers from the usual restrictions? Should legal regulations governing the laying out of funds be reformulated or modified in order to make doctrine reflect economic reality? If so, what rule-making body is best fitted to effect the adjustment of legal rules? If the emerging forms of quasi-public wealth to some degree pro-

40. See Griswold, Spendthrift Trusts $\$ 29$ (2d ed. 1947).

41. Gray, Restraints on the Alienation of Property iii (2d ed. 1895).

42. GRIswold, op. cit. supra note $40, \S 58$.

43. Sce note 34 supra. 
vide "venture" capital, should public funds be withheld from the investment field?

Providing satisfactory answers to such political and economic questions inescapably requires the solution of more peculiarly legal ones. What legal status ought to be given the managers of the funds? Is their position comparable to that of the trustee of the private express trust? Is it like that of the trustee of the traditional charitable trust? Or is it more akin to that of the director or the manager of a private corporation? To what degree should legal status turn on the device adopted for effectuating company or union policy? In view of the considerable economic power concentrated in the hands of the managers, should the legislatures or courts attempt to delineate a unique standing for the administrators of quasi-public wealth? Further questions readily suggest themselves, ${ }^{44}$ and indeed some have been seeking satisfactory resolution for a fairly long time. ${ }^{45}$

Whether or not the misgivings about the rise of institutional wealth are well founded is largely a matter for speculation. It may be that historically, fears engendered by spectacular accumulations of funds have in the long run proved groundless. ${ }^{46}$ But the conditions under which previous accumulations have developed, and their rates of growth, were not the same as those to be found today. Therefore our natural tendency to evaluate change on the basis of past experience might prove misleading. And yet the facts necessary for effective prediction are not available.

This very uncertainty regarding the effects of the emergence of quasi-public wealth is yet another source of disquietude. Any shift in property arrangements has repercussions unforeseen; and the more abrupt the change, the greater the likelihood that it will be resisted-that trends dimly discerned will be viewed with apprehension. In this land of polls, surveys and endless statistics there is little in the way of verified information concerning the political, social and economic consequences of the recent massive changes in property arrangements. However, prediction may be essayed, even though some of it inevitably borders on sheer speculation.

\section{Political, Social and Econonic Effects of the Emergence of Quasi-Public Wealth}

\section{The Impact of Forced Saving}

To the extent that there is a forced deferment of current consumption of goods and services in exchange for a claim to future consumption, freedom

44. E.g., Has the growth of welfare funds had an appreciable effect on the mobility of workers? Will pension plans be used by company, union or both to induce worker conformity? Will extension of pension coverage discourage expansion of the federal social security program?

45. The "vesting" in the employee of the employer's contribution to a pension plan is a matter of common comment in welfare and pension fund literature. For difficulties inherent in the use of the word "vest," see Grax, The Rule Against Perpetuities \$ 108 (4th ed. 1942) ; Leach, Future Interests 255 (2d ed. 1940).

46. Id. at 815 . 
of choice is reduced. Whether one wants to or not, he must forego present use or disposition, and accept instead benefits keyed to loss of earning power or early death. Provision for old age, or for one's dependents and successors, must be made during the productive years, as a social obligation.

If it be conceded that from the standpoint of the community some forced saving on the part of each of its members is desirable, how far can society go before the benefits sought are overshadowed by mischiefs unforeseen? Although it is unlikely that deferred claims will in the immediate future quantitatively exceed the balance awarded the individual for current consumption, it is undeniable that proportionately they are on the increase. And if the tax on current income exacted by government continues to increase there is the possibility that in all ranges of income except the very high, voluntary saving may at some time be markedly restricted, with economic and social consequences of which the following are suggestive.

First, familiar sources of capital might suffer, at least temporarily. The role presently played by the savings institution, the investment house and the private insurer in providing credit for economic expansion, particularly at the local level, is an important one. But the ability of these institutions, as presently constituted, to continue such service is peculiarly dependent upon the voluntary investment of some portion of current income by innumerable salary and wage earners. To the degree that voluntary saving is diminished, the function of the institutional investor is jeopardized. ${ }^{47}$ Further, great corporations-prime targets in the pension drive-rely heavily on retained earnings to finance plant expansion. ${ }^{48}$ Currently, as commentators delight in pointing out," federal tax statutes virtually insure that the ultimate burden of corporate contributions to welfare funds falls largely on the general public. Should the favorable tax structure change, with the result that the final incidence of the welfare contribution was switched to the corporation, the drain on profits might prove too heavy, the growth of retained earnings be stunted and self-financing dwindle. If the impact of forced saving were felt heavily by both employer and employee, the newer forms of quasi-public wealth as a source of capital (and consequently of power) might attain a commanding position. ${ }^{50}$

Second, an unintended combination of forced saving, on the one hand, and high income, gift, estate and inheritance taxes on the other, could have unexpected effects in the long run on freedom of testation and the institution of

47. Dearing suggests that the prospects of receiving an industrial pension will not basically alter the financial programs of those with well-defined savings habits. DEARING, op. cit. supra note 20 , at 174 .

45. Herle, The 20th Century Capitalist Revolytion 37-40 (1954).

49. Boyce, How To Plan Pensions 167 (1950); Cochran, Scientific Emiployee Benefit Planning 5 (1954).

50. Dearing suggests further possibilities:

"If the excess supply of money savings should become chronic, a variety of serious situations might be expected to develop. The most disturbing perhaps would be the emergence of a significant disparity between the capacity to produce and to consume. 
inheritance. Freedom of testation is a relatively new phenomenon, ${ }^{51}$ confined in highly consequential usage to a small proportion of the population, ${ }^{62}$ and nearly always subject to restrictions of one kind or another. But its very existence presupposes both the availability of something to give and considerable discretion for the donor in designating the objects of his bounty. Obviously. if acquisition of surplus income is made inordinately difficult, and the levy on its transfer to dependents and successors set too high, freedom of testation will become an empty concept. Further, to the extent that benefits receivable under welfare plans are available only to members of a rigidly defined class, freedom of choice in designating the objects of one's bounty is reduced. It is commonly assumed that the abolition of inheritance spells the end of class and the advent of socialism; $;^{53}$ but that thesis rests on overly narrow notions about the valuable, and assumes a stability of institutional arrangements that probably does not exist. Nevertheless, any substantial impairment of the process means a striking change in the devolution of wealth as we have known it.

\section{Government Regulation}

Another, perhaps more immediate, effect of the growth of quasi-public wealth is likely to be that pressure for government regulation of retirement, pension, profit-sharing and health and welfare funds will become irresistible. Whatever the event or series of events that will spark government intervention, the ultimate area of vulnerability remains the same: inherent weaknesses in many of the plans themselves. Since they are often hastily drawn, some schemes are subject to manipulation and abuse. ${ }^{54}$ If abuses became rampant, no crisis in the general economy would be required to force drastic revision or even abandonment of a plan, with inevitable defeat of the reasonable expectations of the beneficiaries. And if a plan were financially unsound at its inception, internal changes within the organization of the employer-participant, or within the industry of which the employer is a part, could spell disaster for the fund, even though the general economy remained sound and stable. The occasional failure of an isolated fund covering very few persons is likely to go unnoticed. But a rash of difficulties affecting millions would swell to a shriek the call for supervision which already has been sounded. ${ }^{55}$

This occurred in the 1920 's . . and was a primary factor in the speculative boom and subsequent collapse....

"The second possible consequence of surplus savings would be to increase the longrun money cost of maintaining industrial pensions. ..."

DEARING, op. cit. supra note 20, at 210.

51. CoHen, The Birthright of Esal, in LAw AND the Social Order 27,29 (1933).

52. Cole, Inheritance, 8 ENcyc. Soc. Scr. 35,39 (1932).

53. Id. at 42.

54. Straub, op. cit. supra note 19, at xvii-xviii; Senate Subcommittee on Welfare and Pension Funds, Interim Report, 84th Cong., 1st Sess. (1955).

55. Straub, op. cit. supra note 19, at 139-49; Wallis, Pension and Profit Sharing Trusts, 94 Trusts \& Estates 841 (1955). See Senate Inquiry Urges U.S. Check on Books of All Welfare Funds, N.Y. Times, April 1, 1956, p. 1, col. 1. 
Once the decision to regulate becomes irrevocable, an agency must be selected to do the job. As has so frequently been the case in the past, choice may go by default; but whatever the election, the difficulties confronting any agency undertaking surveillance of a miscellany of plans will be great. Skills developed by the legal profession in developing satisfactory administrative machinery under comparable circumstance will be called into play once again as the regulatory movement gets underway.

Of the consequences to be expected from regulation, one in particular will he of interest to the property lawyer. It is likely that as the role of legislative and administrative directives becomes more important in the field of social welfare, the great variety of device and detail encountered in retirement, pension, profit-sharing and health and welfare plans will disappear. ${ }^{50}$ Permissible channels for the investment of funds will be delineated. The classes and the claims of participants and their dependents will become more or less uniform. The present widespread experimentation in form and function will be a thing of the past.

The period of transition from complexity to relative simplicity may be either confused and chaotic or calm and orderly. But in any event, the role of the legal profession in channeling the change is obvious. For generations lawyers have had the task of reformulating the ill-expressed notions of donors in order to effectuate intention and minimize disappointment among beneficiaries. In undertaking the equally exacting but even more important task of reconstituting diverse plans for the care of dependents and successors on a mass scale, bench and bar will be continuing a work already familiar, but on a larger scale of importance for the community at large. The opportunity to render a public service in the property field will be unparalleled. That the legal profession will seize the initiative is, however, doubtful. If present trends continue, the services of the lawyer will be sought-after the important decisions have been made.

\section{Decline in the Lawyer's' Leadership}

For another effect of the emergence of this new quasi-public wealth is a further passing of power from judges and lawyers to legislators, administrators, trustmen, insurers, labor leaders, labor relations counselors, and so on. Unfortunately, the drift is not new. ${ }^{57}$ Legal historians suggest that for many centuries the designing and developing of property devices, doctrines, and practices were pretty much left to the legal profession. ${ }^{58}$ Certainly many a plan for the care of dependents and successors was frustrated by failure to conform to the

56. Standardization of clauses in insurance policies is attributable in part, at least, to government regulation of the insurance business. A purchaser of insurance buys, in effect, what the insurer has decided to sell as modified by what the regulatory body says the insurer must sell, if he sells at all. As Vance epitomizes the notion: "a policy of insurance is a contract of 'adhesion." "VANCE, Insurance 243 (3d ed. 1.951).

57. See Bradvay, The Bar and Public Relations 56-64 (1934).

58. 7 Holdsworth, History of Englisf Law 355, 384-87 (1926). 
legal formulae worked out by English conveyancers and their counterparts on the bench. ${ }^{59}$ Even in the United States the pre-eminence of the lawyer in property matters was assured until about the end of the nineteenth century. But with the shift from an agricultural to an industrial economy, with the rise of the metropolitan community, and with the increased utilization of the corporate form of organization, the importance of land law declined. ${ }^{\text {gn }}$ Its attenuation was accompanied by a partial transfer of legal functions from the lawyers to other emerging professional groups. Heads of families seeking security for dependents turned to insurers for advice and counsel. Businessmen vexed by financial problems sought out their accountants. The family lawyer of familiar fiction all but disappeared.

That is not to suggest that lawyers have had no part in the creation and development of the manifold plans for security advanced during the past fifty years. But it is probably demonstrable that their role in that connection has not been a dominant one. Perhaps as a group they prefer that the policy decisions be made by community groups closer than they to the pulse of popular will, even though it is inevitable that the legal profession will be called in to add flesh to the skeletal schemes designed by others. But the fact remains that judgments affecting property arrangements of innumerable individuals have been made-and will be made-far outside courtroom walls and lawyers' chambers, by men with little knowledge of legal doctrine, and perhaps even less in the way of respect for it.

\section{The Tax Structure}

A consequence of the publicity surrounding the appearance of union welfare funds is a growing public awareness of the close relationship between the tax structure-federal, state and local-and the evolution of all forms of institutional wealth-corporate, union and philanthropic. Commercial corporations have been granted tax preferences only sporadically, whereas charitable trusts and nonprofit corporations have been accorded favorable tax treatment more or less continually. ${ }^{61}$ The federal tax statutes designed to promote the multiplication of union-sponsored security arrangements ${ }^{62}$ are perhaps results of the

59. For a brief discussion of the rules established in some classic cases, see Leach, Perpetuities in a Nutshell, 51 HARv. L. Rev. 638, 642-46 (1938).

60. Abrams, Revolution in Land 28 (1939).

61. "Tax" exemption at an early date led to restrictive legislation affecting charitable institutions. The impact of feudal incidents such as wardships and marriages (roughly comparable to modern inheritance taxes) could be evaded for a time by conveyances in mortmain. As Holdsworth put it: "If a man gave land to a religious corporation the lord got a tenant who never died, who was never under age, who could never marry, who could never commit felony." Holdsworth, Historical Introduction to the Land Law 109 (1927). Consequently, statutes were enacted from time to time preventing unauthorized alienations in mortmain. Plucknetr, A Concise History of the Conmron Law 510 (4th ed. 1948) ; Plucknetr, Legislation of Edward I 94-102 (1949).

62. E.g., Int. Rev. Code of 1939, \$ 23(p), 53 Stat. 15 (now Int. Rev. Code of 1954, $\S 404$ ) ; Int. Rev. Code of 1939, $\$ 165$, 53 Stat. 67 (now INT. Rev. Code of 1954, § 401). 
notion that movements for the relief of the poor, the sick and the orphaned are to be encouraged; but whatever the origins of the preference, welfare funds are in large part accumulated with funds otherwise payable to the Treasury.63 Whether the indirect subsidization achieved through the tax exemption and deduction devices should be extended, restricted or abolished depends, of course, on the social utility of the activities pursued through institutional wealth. With increasing government demands for additional revenue, it becomes important in the interests of both the individual bearing the tax burden and the government seeking additional tax resources to define the objectives of government policy and to determine whether or not a rational and consistent tax structure has emerged from the random development that has characterized the emergence of quasi-public wealth. Obviously, modification of policy ought to proceed against a background of fact; and thoroughgoing surveys of institutional hold-

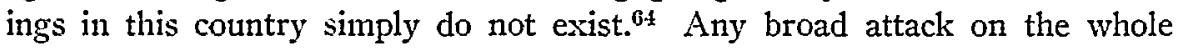
problem of indirect contributions to institutional ventures must await the gathering of data not now available.

\section{Charities in the Shadow}

Another development in the property field has been plainly discernible for some time. There is still a continual quantifative increase in philanthropic holdings, ${ }^{65}$ but as the place accorded the newer forms of quasi-public wealth broadens, activities traditionally called "charitable" are being confined to ever-narrowing channels, and in some areas displaced altogether. For example, the orphan has been, and continues to be, the object of organized charity. But to the extent that the new welfare funds provide for dependents and successors of a participant so that the family group remains intact on the death of the breadwinner, the objects of traditional charity are reduced in number. There is much charitable work still done among the old and the infirm, but similarly, to the degree that retirement and illness benefits are made available under the multifarious security plans now in operation, the necessity for calling on organized charity is obviated. It may be, in sum, that traditional charity will eventually be forced into a relatively insignificant role; in the future, charitable activity in this country may be confined to religious and educational undertakings.

But should the range of charitable operations remain comparatively broad, welfare funds will nevertheless have an impact. If abuses in the operation of welfare funds induce government supervision, in time such supervision is likely to be extended to other charitable activities. Further, the business-like characteristics of some of the new schemes may invite traditional charities to

63. See authorities cited in note 49 supra.

64. "It would take years and a real fortune to determine what all units of organized charity are doing under present circumstances, particularly in view of the lack of accounting procedures." Wynn, Charitable Organizations, 92 Trusts \& Estates 762,765 (1953).

65. In an unpublished report made at the end of a year's study of charitable wealth, Mr. John E. Sullivan, Research Assistant, Ohio State University College of Law, estimated the value of philanthropic holdings in the United States at about $\$ 30$ billion. 
take on an appearance of "efficiency," to avoid unnecessary duplication of function, and to conform to rather strict standards of propriety. Again, contributions by employers and employees to their own security plans perhaps reduce to some degree the portion of current income that might otherwise be contributed to organized charity. A participant storing up for his own future may be less willing to give for the benefit of those whom he considers to be less far-sighted than himself. ${ }^{66}$ Finally, to close the circle, as the proportion of the newer forms of quasi-public wealth increases, and transmission of property on a group basis becomes commonplace, beneficiaries of traditional charity may one day look upon themselves not as objects of the largesse of others, but as holders of "rights" in the general wealth of the community.

\section{A Look at the Present and the Future}

Devolution of wealth on a group basis is not new, even to Anglo-American law. Some share of all wealth, however small, has invariably been in government hands, and the charitable trust is a time-honored institution for passing property from generation to generation in perpetuity. However, popular conmentary and taught law alike have tended to stress transmission of wealth from the individual to his dependents and immediate successors in interest. Political and social theory have often assumed that the alternative to private property is state socialism. Indeed, there is historical justification for emphasizing the polarity of state ownership, on the one hand, and individual enterprise, on the other. Tyranny has been thought to be the concomitant of the one; freedom, the inevitable counterpart of the other.

Any thoughtful person will readily concede that community ownership of some limited share of all wealth is not necessarily bad, and no lawyer cognizant of the great property decisions would contend that private property doctrines invariably produce socially desirable results. But the notion is deep-seated that the traditional arrangements for the transmission of wealth from generation to generation represent the ideal balance between transfers on a strictly individual basis and transfers under some communal plan. Any suggestion that the relative positions of the two systems be changed in any appreciable degree is, in consequence, likely to be viewed with some apprehension.

But misgivings or no, our democratic society is now faced with a fait accompli: an evolving system of wealth devolution, more or less an accidental by-product of the rise of the corporate system of ownership, which partakes of both antithetical systems of wealth transmission; which, despite its formal facade. falls neatly into none of the traditional categories of property devices; and which poses political, economic and legal questions that have no pat answers. How did this phenomenon come upon us unaware $?^{37}$ The number of persons affected,

66. More than half of all philanthropic giving comes from low-income groups. ANDrews, Philanthropic Giving 56 (1950).

67. "It is of the essence of revolutions of the more silent sort that they are unrecognized until they are far advanced." Berle \& Means, The Modern Corporation and Private PROPERTY vii (1932). 
the size of the funds involved and the publicity attendant upon the emergence of a new form of quasi-public wealth have assured a higher degree of interest in evolving security plans than was probably evoked by comparable property developments of the past. Where were those who would ordinarily detect property change, predict its drift and suggest its impact upon familiar institutions?

Perhaps a partial explanation for the failure to chart trends and explore implications lies in the rate of change in forms and practices. Retirement, pension and profit-sharing plans are not new. But their rate of growth during and since the second World War has been phenomenal. A people engaged in shaking off a great depression, fighting a global war and resuming a normal life in its aftermath have found time for little more than passing speculation about the funds burgeoning around them. The pace has been too fast. Thought has tended to be afterthought. For something over two centuries English jurists sought to delineate the ramifications of the Rule Against Perpetuities. It is unlikely that comparable luxury will be afforded American judges in working out the intricacies of the security schemes produced by the social revolution of the nineteen thirties.

Then too, attempts to transmit wealth through group arrangements have followed no consistent pattern. Life insurance companies did not attain their position of financial strength and economic power through sheer benevolencea part of their impetus has always been frankly commercial. The movement of labor unions into the welfare field was in some respects fortuitous : concern for dependents and successors of the wage earner has invariably been subordinate to thrusts for power.

Finally, although change has occurred, not all-or even a large part-of property arrangements have been affected. For generations past, in the face of enormous difficulties, individuals have succeeded in amassing wealth and transmitting it to their successors; and today, despite the cries of outraged taxpayers, they are still doing so, for neither income nor inheritance taxes are confiscatory. The thrust of welfare funds has been particularly dependent upon the strength of organized labor, and many millions of workers, still unorganized, have not set their sights beyond the mere wage increase. ${ }^{68}$ Even where the pressure for security measures exerted by employee groups has resulted in welfare schemes of various kinds, the charge on individual current incomes has not been exorbitant,

68. See Kerr, Social and Economic Consequences of the Pension Drive, in Natronal Industrial Conference Board, Handbook on Pensions 84 (1950):

"The impact of any given pension plan varies enormously from company to company-much more than changes in wages and hours. The prewar plans were limited almost entirely to companies with 500 or more employees. There are 5,000 such companies in the United States, or less than one tenth of $1 \%$ of all firms. Ninetyfive per cent of the business firms, or 3,250,000 have fewer than twenty employees. The large firm, the old firm, the prosperous firm may be able to absorb a pension plan quite readily.... Not so the many small firms. Even in prosperous years, 5\% to $10 \%$ fail annually.... Adequate financing at the outset . . is beyond the grasp 
whatever may be its effects in the aggregate. The law of property, trusts, wills and future interests is still taught, studied, re-stated and manipulated; it is remarkable in its vigor. Therefore, there need be no rush to form battalions to save private property and the institution of inheritance. Whatever the impact quasi-public wealth will have upon them, their sudden eclipse is not likely.

But even so, it might be well for society to take a thoughtful look at the trends in property practices, and to consider their implications. Currently, the difficulties attending the use of the newer forms of quasi-public wealth have a familiar source: abuse. Virtually no property device has escaped perversion for long, and it is therefore not surprising that both the commercial and the nonprofit corporations have been manipulated for questionable purposes. But reform follows excess, and it is beyond question that both forms of organization are here to stay. If this is so, it might prove desirable for property lawyers to reconsider the desirability of continuing to refine still further the legal doctrines concerning direct restraints on alienation, when all about us the indirect restraints worked by institutional holdings of wealth are multiplying at a fantastic rate. What use is it to rationalize the Rule Against Perpetuities, if large aggregates of claims are to be exempted from its operation by legislative fiat $7^{00}$ Making a studied choice between voluntary saving, on the one hand, and forced deferment of consumption, on the other, is preferable to letting the decision go by default. Forthright elimination of such corruption as exists in the administration of welfare funds is likely to be much more effective than alleviation of its disrupting effects. Re-evaluation of encouraging the growth of all forms of quasipublic wealth through manipulation of the tax structure is certainly in order. The place of charitable activities in modern society bears exploration in view of the recent shifts in property arrangements.

And even if we choose to drift rather than to set a course, might not the legal profession best meet its obligations to society by taking account of the fact that the old order of wealth devolution is gradually being modified? Quasi-public wealth has long been with us, but never before has it assumed the relative

of many small firms. Full funding of a pension, which is the only way to assure the employee security if the company fails, costs approximately $\$ 4,000$ for one employee aged forty-five if he is to retire at age sixty-five with a $\$ 50$ per month pension. The coverage of workers in industries with a casual labor force is almost impossible."

69. See 6 American Law of Property $\$ 24.61$ (Casner ed. 1952). Professor Fratcher lists a number of states which exempt trusts for employees from their common law or statutory rule against accumulations. Fratcher, $A$ Half Century of Trust Law, 93 Trusts \& Estates 275, 278 n.26 (1954). Cf. Wynn, supra note 64, at 765:

"If the Federal government becomes convinced that organized charity should not be free from the application of the rules [against perpetuities and accumulations], the state statutes embodying the rules will become of less and less importance. For example, under the Revenue Act of 1950 and the Treasury regulations, there is an inference, if not more, that organized charity must not accumulate its income, if it is to retain its tax advantages. Few units of organized charity will accumulate large amounts of income, even though permitted by state law to do so, under these circumstances." 
importance that it enjoys today. Might not a greater proportion of our best legal minds, carefully trained in the property lessons of the past, devote their talents to recognizing the emerging forms of wealth, to delineating their characteristics, and to making them more serviceable than their traditional counterparts? The representative "heir" of the future may well find his inheritance in the perforations of a tabulating machine card. From the standpoint of public service, might not formulation of rules governing the transmission of wealth on a group basis rank with reformation of doctrines dying through desuetude? The opportunity is surely there. Will the lawyers lose once again to competing professional groups?

Whatever the choice of the lawyers, the community of which they are a part is facing the fact that the young support the old ${ }^{70}$ that the strong sustain the weak, that man is not an island. For however formidable the legal doctrine, however complicated the institutional arrangement, however impressive the array of recorders, the share of goods and services allotted each of the living, and the respect accorded the hand of the dead, are alike charges on the yield of the productive facilities of the community at any point in time. ${ }^{71}$ Any rational arrangement for meeting the demands of old age and the needs of dependents and successors must take account of that fact.

70. "More than a third (36 per cent) of the nation's old people have no personal income at all; they are dependent on savings, relatives, friends and charity. Another 38 per cent receive less than $\$ 1,000$ a year. ..." ...65 and Over, Collier's, Dec. 9, 1955, pp. 32, 35.

71. See Dean, Accounting for the Cost of Pensions-A Lien on Production, Harv. Bus. Rev., July 1950, p. 25; id., Sept. 1950, p. 102. 


\section{THE YALE LAW JOURNAL}

\begin{tabular}{lll}
\hline VolUMe 65 & MAY, 1956 & Number 6 \\
\hline
\end{tabular}

\author{
DAvid B. ISBETL \\ Article and \\ Book Review Editor
}

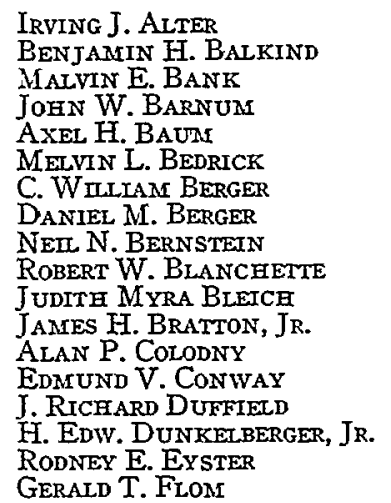

\section{Norbert A. SCHLEI \\ Editor-in-Chief}

Geraid M. Doppent

JON O. NEWMAN

RICHARD H. PERSHAN

Note and Comment Editors

ALVIN FRIEDMAN
VICTOR S. FRIEDMAN
MORTON I. GREENBERG
ROBERT J. HARRIS
GEORGE C. HASTINGS
IRA MICHAEL HEYMAN
BUD GEORGE HOLMAN
WILLIAM E. HUTH
CHARLES. ISAAC
LLOYD J. KENO
LAWRENCE R. KLEIN
DAVI KIINGSBERG
HAROLD S. LEVY
IRWIN A. IEVY
JULIUS LLWIS
ARTHUR L. LIMAN
BARBARA A. LINDEMANN

\author{
Stephen J. Pollak \\ Managing Editor
}

Ralph C. MEnapace, JR.

EDWARD A. MILLER

GABRIEL ORECH KOFF

OtIS P. PEARSALL

ROBERT S. REDMOUNT

MIARVIN N. RIMIM

BERNARD S. RobBINS

RAy Maury ShaINBERg

WALTER E. SHUTTLEIVORTH

BARRY SILVERSTEIN

ROBERT J. SISK

ARLEN SPECTER

JoHN T. SUBAK

Chardes W. Thomiasson

ChaRLES H. Vetvona

FraNk E. G. WeIL

STEPHEN A. WEINER

HOWARD P. WILXENS

Marte McMation

Business Secretary

The Yale Law Journal mourns the death of FREDERICK CHARLES HICKS

Librarian Emeritus of the Yale Law School

\section{CONTRIBUTORS TO THIS ISSUE}

JERome Hald. Ph.B. 1922, JJD. 1923, University of Chicago; Jur.Sc.D. 1935, Columbia University ; S.J.D. 1935, Harvard University. Professor of Law, Indiana University Schnol of Law. Author: Theft, Law and Soctety (1935, 2 d ed. 1952) ; ReAdings in JuRisprudence (1938); General Principles of Crminal Law (1947); Cases and Readings on Criminal Law and Procedure (1949); Lining Law of Democratic Society (1949). Editor: 20th Century Legal Philosophy Series (7 vols., 1945-).

RoBert J. Lynn. B.Sc. 1942, J.D. 1948, Ohio State University ; J.S.D. 1952, Yale University. Associate Professor of Law, Ohio State University College of Law. 